\title{
A Review on The Phytochemical and Pharmacological Properties Barringtonia Asiatica
}

\author{
Isaac John Umaru*, Fasihuddin Badruddin Ahmed', Hauwa A Umaru², Kerenhappuch I Umaru ${ }^{3}$ and Benedict \\ Samling 1
}

${ }^{1}$ Faculty of Resource Science and Technology, University of Malaysia Sararwak, Kuching, 94300 Kota Samarahan Malaysia

${ }^{2}$ Department of Biochemistry Moddibo Adama University Yola Adamawa state

${ }^{3}$ Department of Biochemistry University of Maiduguri Borno State

Received: 恝 September 9, 2018; Published: 眥 September 18, 2018

*Corresponding author: Isaac John Umaru, Faculty of Resource Science and Technology Sarawak, Kuching, Federal University, Malaysia

\begin{abstract}
A review of Barringtonia asiatica considered to be a mangrove associated species is made to update its Phytochemical and Pharmacological Properties which is claimed to be a broad-spectrum medicinal property. Barringtonia asiatica was commonly used in various country of the world for treatment of liver disorder, diarrheal disease, eye disease, as well as antifungal and antibacterial, as well as chest pains and heart troubles. It was also considered a fish killer; this has been identified as a source of Natural products with potentials as an antitumor. The aim of the present review is to provide detailed information regarding geographical distribution, phytochemicals and pharmacological properties of this plant.
\end{abstract}

\section{Introduction}

Barringtonia asiatica is a species of Barringtonia native to mangrove habitats on the tropical, it is a common plant in the Malaysian Mangroves and wetlands such as the Kuching wetlands Sarawak and Bako National Park, it is also found in tropical Africa, Nigeria and Madagascar. Its large pinkish-white, pompon flowers give off a sickly-sweet smell to attract bats and moths which pollinate the flowers at night. It is grown along streets for decorative and shade purposes among Sarawakian houses in Malaysia and it's also known as Box Fruit due to the distinct box-shaped of the fruit, it is a medium-sized tree growing to $7-25 \mathrm{~m}$ tall [1]. The leaves are narrow obovate, $20-40 \mathrm{~cm}$ in length and $10-20 \mathrm{~cm}$ in width matured foliage colour is green, smooth glossy shiny leathery thick simple and evergreen. It is used as sausage food among the native of sarawakian in the kampong as well as a medicinal plant, inhabitants of several West African countries, Nigeria and the Polynesian Islands use liquid from the crushed bark of Barringtonia asiatica to treat stomach-aches, the top leaves from this tree are squeezed into water and the liquid taken orally. The stem bark of the plant is pinkish grey [2]. The plant when mature the bark texture is smooth and woody. The root type is fibrous and has pronounced tap root.
The Fruit, due to its distinct square like diagonals jutting out from the cross section, it gives a semi spherical shape form from stem altering to a sub pyramidal shape at its base. The fruit measures $9-11 \mathrm{~cm}$ in diameter, where a thick spongy fibrous layer covers up to 4-5cm diameter. The fruit is dispersed in the same way as a coconut by ocean current and is extremely water-resistant and buoyant [3]. It can survive afloat for up to fifteen years [1]. When washed ashore and soaked by rainwater then the seeds germinate.

All parts of the tree are Poisonous, and the active poisons include saponins. The box fruits are potent enough to be used as a fish poison. This Angiosperm of a flowering seed plant has a perennial life span with an autotrophic mode of nutrition, the seeds have been used when ground to a powder form to stun or kill fish for easy capture, it suffocates the fish living no effect on the flesh [4]. The active components may be found in the root, bark, stem, and leaves of the identified plant [2]. The seeds of Barringtonia asiatica are used in the Pacific Islands by scraping the seeds on lava rocks by shallow tidal pools and washing the scrapings into the water. This method and the methods described above result in dead or stunned fish rising to the surface in a short time where they are 
collected by hand, then cooked and eaten with no apparent harm to the consumer. Below is the isolated structure of plant-based fish poisons Figure 1; Ranuncoside VIII [2]. The seeds have been found to contain about $2.9 \%$ of fixed oil consisting of olein, palmitin, and stearin; gallic acid 0.54\%; and a glucoside, Barringtonia $3.271 \%$ (C18H2507CH3) (5), and 1\% of a substance designated as barringtogenetic [5,6]. Figure 2 shows the Natural habitant of Barringtonia asiatica and seed of Sarawak Kampong.

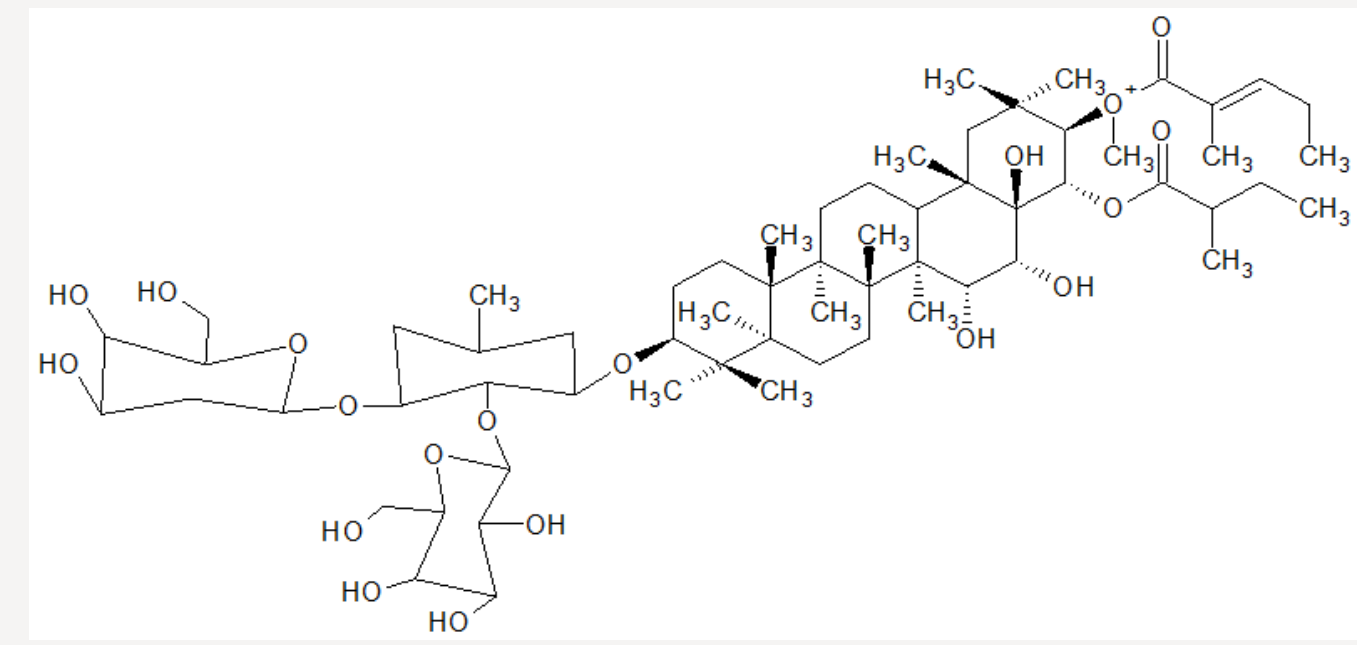

Figure 1: Ranuncoside VIII

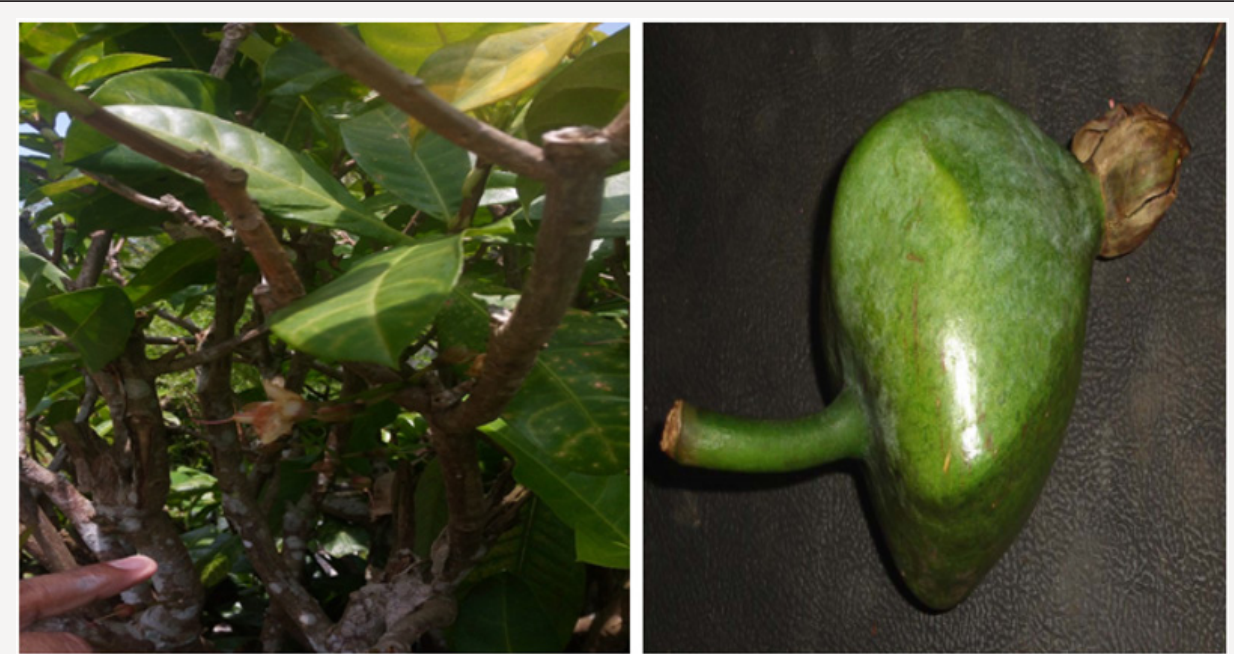

Figure 2: Natural habitant of Barringtonia asiatica and seed of Sarawak Kampong.

Even though all the parts of the tree are poisonous, the seeds are used for killing the fishes. The ichthyotoxic property of the seeds is attributed to Saponin in the Barringtonia [7]. Both mature (ripened) and immature (green) fruits are collected for this purpose. In case of mature fruits, it is collected from underneath the tree or in the beach areas since, it drops off once the outermost layer turns from green to brown and the immature fruits are plucked directly from the tree. The fruit are stored in a safe place, since it is poisonous, in order to avoid accidental consumption of these fruits by children or livestock. The collected matured and immature fruits are cut and stripped off the outer layers and the seeds are separated. Later it is grated on the same day at the fishing site or a day before venturing into sea. The lowest low tides and preferably full moon day time is selected for this type of fishing. The spring tide of the new moon fills the pools and inundated places with sea water in the intertidal area, where the water gets stagnated along with fish for longer duration and is exposed during low tide. For selecting the suitable area, skilled fishers visit the intertidal area and check the presence of fish and depth of the stagnated waters, seasonal streams, fresh water stagnation were harvested seasonally using the Barringtonia asiatica seed.

\section{Taxonomy}

It is one of the species in Plantae kingdom from genus Barringtonia which are classified under the family of Lecythidaceae. The Barringtonia genus got its name after Hon. Daines Barrington, 1727-1800, an English nobleman, lawyer, antiquary and naturalist who wrote a book on English trees. Botanically, the 'asiatica' term at the later part of the scientific name was original name of Mammea asiatica) by Carl Linnaeusnin his Species Plantarium [8]. 
Kingdom: Plantae.

Subkingdom: Viridiplantae.

Infrakingdom: Streptophyta.

Superdivision: Spermatophytina.

Class: Magnoliopsida.

Superorder: Asteranae.

Order: $\quad$ Ericales.

Family: Lecythidaceae.

Genus: Barringtonia.

Species: Barringtonia asitica (L.).

\section{Origin and Geographical Location}

Barringtonia asiatica which is considered a mangrove associate, can also be found in tropical rainforest areas, open lowlands and thickets and in. Occurring always near water: along river banks and in fresh water swamps, and occasionally in the less saline areas of mangrove swamps, where it may develop pneumatophores. The species cannot tolerate even light frost. It favours the wet tropical, moist topical and wet subtropical climatic zones. Barringtonia has three distinct areas of species diversity they are the Malay Peninsula, Borneo, and New Guinea. There are a few species distributed across the Pacific as far as the Marquesas Island and two reach East Africa and Madagascar [9].

\section{Morphology of Barringtonia asiatica}

\section{Habitat}

The genus demonstrates a wide range of growth forms, Barringtonia asiatica is confirming to the models Leeuwenburg's and or Champagnats model.

a) Stem: The bark of Barringtonia asiatica is soft, fibrous, but however, thick in most species. The stem grows episodically and show marked segmentation of the axes with prominent leaf scars.

b) Leaves: Leaf size varies from small to medium sized lanceolate leaves in the leptocaul species, 5-20 3 3-15 cm, to huge obovate-lanceolate leaves to $20-40 \mathrm{~cm}$ in width

c) Fruit: Fruit produced as mentioned earlier, is otherwise aptly known as the Box Fruit, due to distinct square like diagonals jutting out from the cross section of the fruit, given its semi spherical shape form from stem altering to a sub pyramidal shape at its base. The fruit measures $9-11 \mathrm{~cm}$ in diameter, where a thick spongy fibrous layer covers the $4-5 \mathrm{~cm}$ diameter. The fruit is dispersed in the same way as a coconut by the ocean current and is extremely water-resistant and buoyant [10]. It can survive afloat for up to fifteen years [1] it was one of the first plants to colonise Anak Krakatau, when this island first appeared after the Krakatau eruption [11], When washed ashore, and soaked by rainwater, the seeds germinate. In the fruits several seedlings often emerge from a single seeded fruit of Barringtonia asiatica [9].

d) Flowers: The flowers of Barringtonia asiatica open sequentially and acropetally. they have sparsely flowered, erect inflorescences. The flowers are generally short-lived, and may be diurnal or nocturnal

\section{Phytochemicals}

Barringtonia asiatica species, the fish killer has been identified as a source of natural products with potentials as an antitumor [12-14]. Its cytotoxicity data showed strong correlation with costly cytotoxicity test using human cancer. As anti-victor disease Dengue-fever [15]. Barringtonia asiatica has a potential of wound healing $[16,17]$. Study on most Barringtonia species from all parts of the world, Africa, Asia, India, China and Northern America have been widely conducted that led to the isolation and identification of some physicochemical active compounds such as amides, alkaloids, lignans, flavones, flavanones, terpenes and steroids etc. [18]. The crude methanol extract of leaves, fruits, seeds, stem and root barks of Barringtonia asiatica and subsequent petrol, dichloromethane, ethyl acetate and butanol fractions exhibited broad spectrum antibacterial and antifungal activity [20]. Antifungal activity of the plant has also been reported by others [20]. The methanol extract of the seeds yielded two major saponins. Their structures have been elucidated as 3-0- [[betaD-galactopyranosyl (1-->3)-beta-D-glucopyranosyl (1-->2)]-betaDglucuronopyranosyloxy]-22-0-(2-methylbutyroyloxy)-15,16,28trihydroxy-(3beta,15alpha,16alpha,22alpha-olean-12-ene and 3-0- [[beta-D-galactopyranosyl (1-->3)-beta-Dglucopyranosyl (1-->2)]-beta-D glucuronopyranosyloxy]-22-0-[2-(E)-methyl-2butenyloyloxy]-15,16,28-trihydroxy(3beta,15alpha,16alpha,22alpha)olean-12-ene. Both saponins showed antifeedant properties against the larvae of Epilachna [21,22].

The elucidated compounds from the methanol extract of the seeds of Barringtonia asiatica, and their structures mainly by two-dimensional NMR spectroscopy as; 3-0-\{[âD-galactopyranosyl(1f3)-â-D-glucopyranosyl(1f2)]-â-Dglucuronopyranosyloxy -22-0-(2-methylbutyroyloxy)15,16,28-trihydroxy-(3â,15R,16R,22R)-olean-12-ene (1), and 3-O-\{[â-D-galactopyranosyl(1f3)-â-D-glucopyranosyl(1f2)]-â-Dglucuronopyranosyloxy\}-22-0-[2(E)-methyl-2-butenyloyloxy]15,16,28-trihydroxy- (3â,15R,16R,22R)-olean-12-ene (2). There has been surprisingly little published work on the isolation of natural products from Barringtonia asiatica. They extracted a mixture of saponins (A1-barrinin) from Barringtonia asiatica. On acidic hydrolysis, A1-barrinin produced a mixture of sapogenins (A1-barrigenin), together with a mixture of several sugars that were later shown to be fucose, galactose, glucose, and glucuronic acid in a ratio of 1:2:2:2. On basic hydrolysis, A1-barrigenin gave 
two aglycons (A1-barrigenol and A2-barrigenol) together with tiglic acid. In 1967 the structure of A1-barrigenol was deduced as 3â,15R, 16R,22R,28â-pentahydroxyolean-12-ene (3) from 1H NMR spectroscopy. A2-barrigenol was found by the same authors [21]. to be identical as camelliagenin $\mathrm{A}$, whose structure had been deduced as 3â,16R,22R,28â- tetrahydroxyolean-12-ene6 (4), i.e., 15-deoxy-
A1-barrigenol. Tanor et al., [18], reported gc-ms result of methanol extract of Barringtonia seeds which indicated three triterpenoid saponin, namely 2.4-bis-(1.1-dimethyl ethyl)-methylcarbamate (5), 4-dodecylphenol (6) and 2.6 bis-(1.1-dimethylethyl)-4-dimethylmethylcarbamate (7) (Figures 3-5).

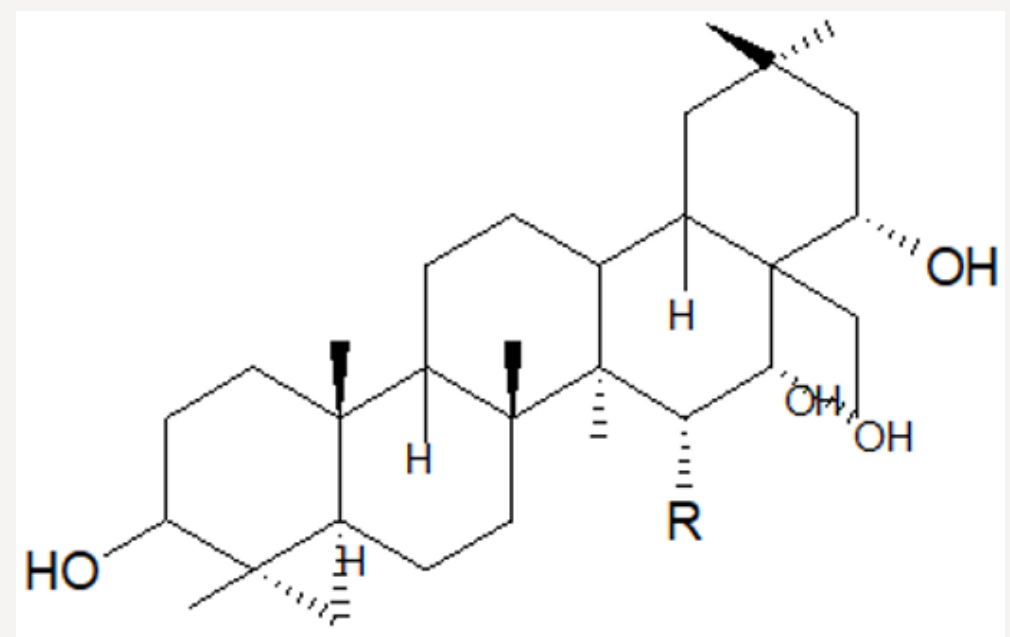

[1. $\mathrm{R} 1=\mathrm{OH}, 2 . \mathrm{R} 1=\mathrm{H}]=[1]$

Figure 3.

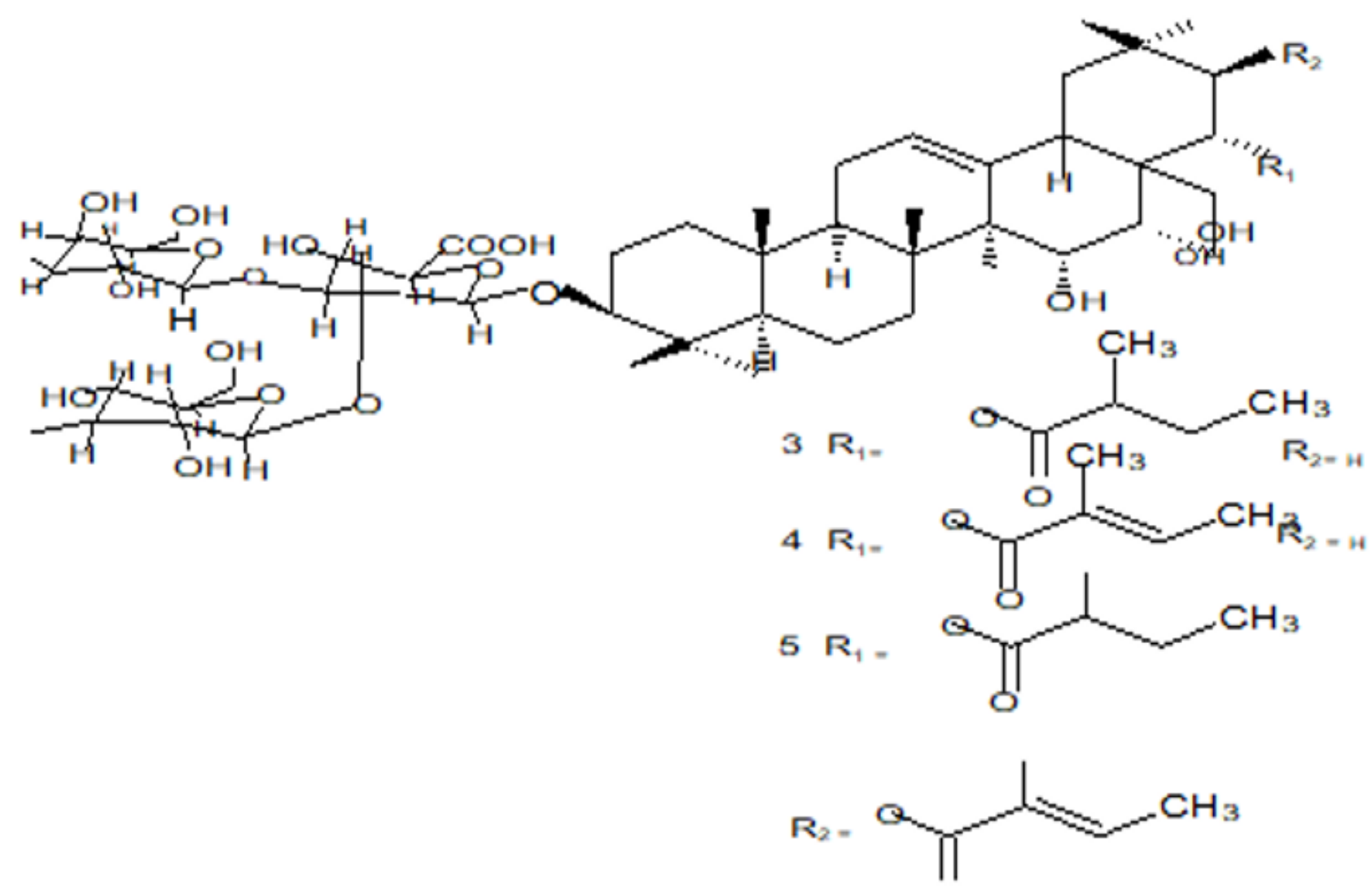




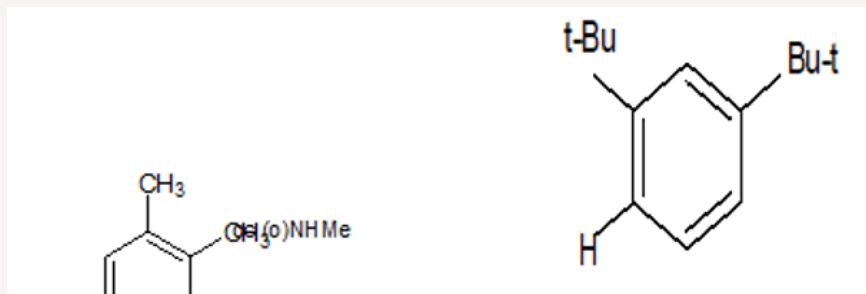

[5]

Figure 5.

\section{The Structure of Chemical Constituents Barringtonia}

\section{Asiatica}

Iwashina \&Kokubugata., [23]. in their study on Flavonoid properties of the Leaves of Barringtonia asiatica (Lecythidaceae), they reported Six C-glycosylflavones and four flavonol O-glycosides were isolated from the leaves of Barringtonia asiatica. Of their flavonoids, four flavones and four flavonols were identified as isovitexin (8), vitexin (9), isoorientin (10) and orientin (11), and kaempferol 3-0-glucoside (astragalin,5) (12), kaempferol 3-0-rutinoside (nicotiflorin,) (13)), quercetin 3-0-glucoside (isoquercitrin,) (14) and quercetin 3-0-rutinoside (rutin,) (15), respectively. Other two were unidentified C-glycosylflavones. Though ellagitannins were also present in the leaves, they were not characterized. it was presumed that major flavonoids of the Lecythidaceae were not only flavonols such as kaempferol and quercetin but also C-glycosylflavones such as isovitexin, vitexin, isoorientin and orientin (Figures 6-13).

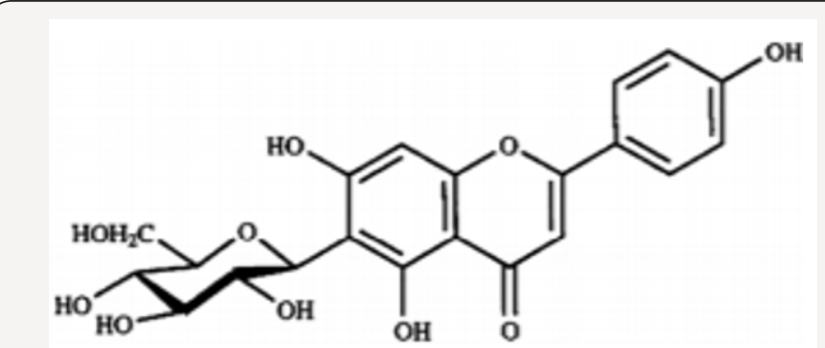

Figure 6.<smiles>CC1(CO)O[C@H](c2c(O)cc3oc(-c4ccc(O)c(O)c4)cc(=O)c3c2O)[C@@H](O)[C@@H]1O</smiles>

Figure 7.

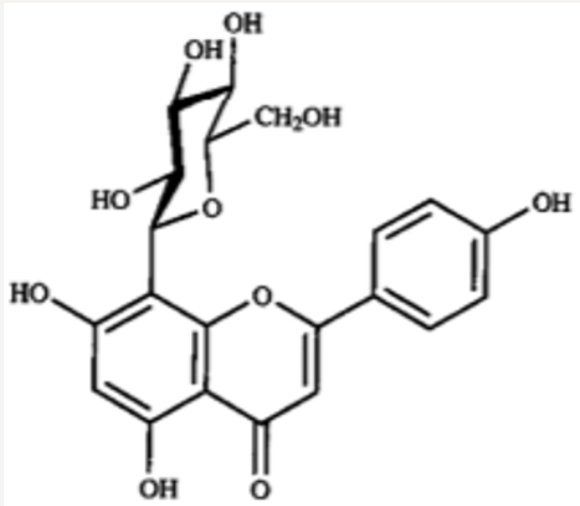

Figure 8.

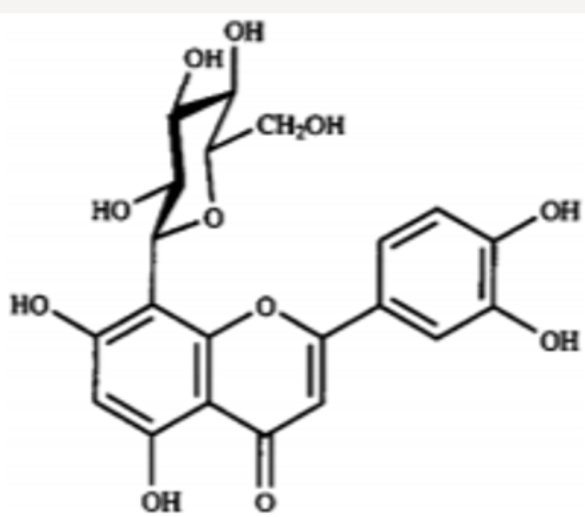

Figure 9.

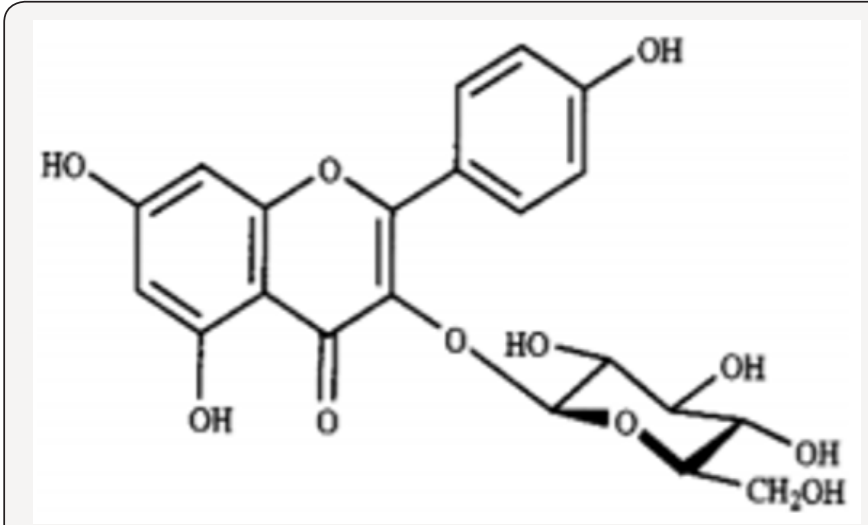

Figure 10. 


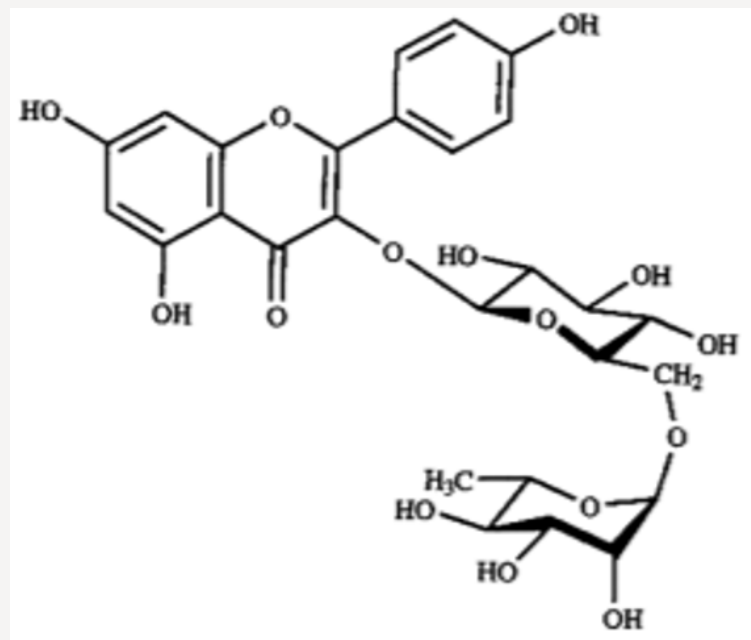

Figure 11.

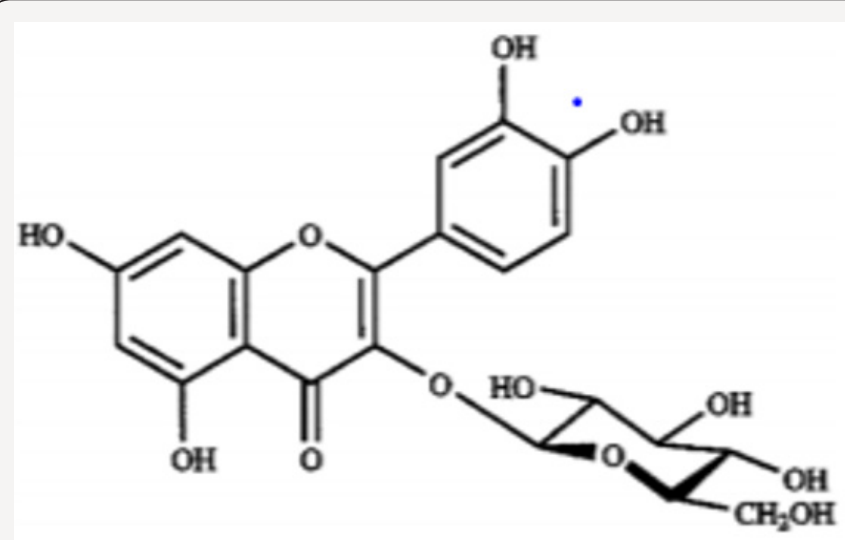

Figure 12.

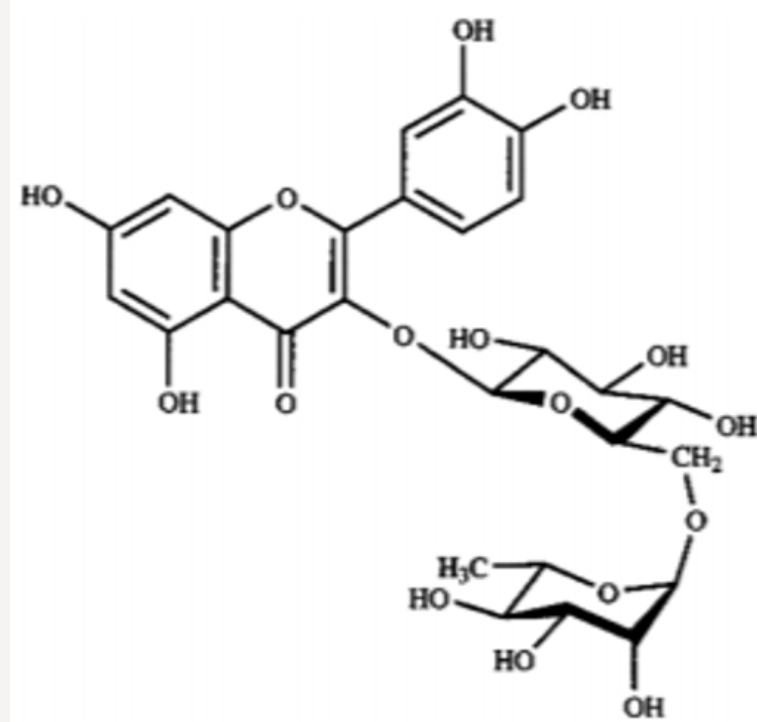

Figure 13.

\section{Pharmacological potentials}

Little studies have been done regarding the biological activities of Barringtonia asiatica [24]. The fruits and seeds of barringtonia asiatica are used as fish poison, the fruit juice from the leaves are applied to stomach ache and rheumatism, seeds as vermifuge, and the bark for treatment of tuberculosis. The crude extract of barringtonia asiatica seeds exhibited high biological activity in the brine shrimp hatchability and lethality assay and the fractions of the extract of leaves, stem-bark and roots exhibited a broad spectrum antibacterial and fungal activity [25]. The hexane leaf extract as reported by [26], in their studies on the antibacterial and cytotoxicity test showed the potential of Barringtonia asiatica extract as lead agent in the development of new drugs for pathogens. The seed was reported to have piscidal activity and the oleanane glycoside ranuncoside was elucidated as the principal compound responsible for the activity [27]. It was also reported that the flavonoid compounds of Barringtonia asiatica have been isolated and has a biological activity [23]. The local traditional practitioners were utilizing various parts of plant such as leaves, bark, roots, fruits and coconut oil etc. for preparing the medicines and to treat various ailments like cough, fever, headache, body pains, wounds, arthritis, skin disease, hair loss, jaundice. The leaves of Barringtonia asiatica tree are squeezed and juice applied over wounds or injuries as a pain reliever. The juice is also used for deworming the human beings. The leaves of the plant together with coconut oil when heated and the extract decanted to remove the fibres of leaves. The dosage and medication time varies with the age of the patient. As reported by [28]. The leaves are also found used for curing fracture and wounds. Experiment conducted by Dam Roy in [29] they reported that, using raw Barringtonia asiatica fruit on adult predatory fishes showed that it is effective in killing such predators as Elops machnata, Therapon jarbua and Megalops cyprinoides.

There has been an interest in the use of the A study on the bark of Barringtonia asiatica which was analysed by [16], concluded that treating wounds with the powdered extract from the bark of Barringtonia asiatica has the ability to accelerate the healing process. In their results they also suggest that treatment with an alcoholic extract of Barringtonia asiatica may have a beneficial influence on the various phases of wound healing like epithelialization, collagen synthesis, and wound contraction, which results in the faster healing of the wound. Thus, the wound healing potential of the Barringtonia asiatica extract may be as a result of the presence of a mixture of constituents including flavonoids and tannins [16]. However, Barringtonia asiatica spp collected from the Vailima Botanical garden is known for its traditional use for treatment of skin sores [30]. In traditional Samoan medicine, its fruit or bark is also used to treat yaws, where by the seed are used to treat ringworm and the bark is used in treatment tuberculosis. In the Solomon Islands and Samoa, it is used to stun fish [31], the wood is sometimes used to make parts of canoes [31]. However, these pharmacological activities are likely to arise from the phytochemicals found in the extracts of Barringtonia asiatica, which include alkaloids, flavonoids, carbohydrates, glycosides, tannins, terpeniods, and phenols as reported by Gorre et al. [31]. 
Recent research has shown that methanol extract of the seeds of Barringtonia asiatica, when coated on leaves of various Solanum species, was reported to be a powerful antifeedant toward larvae of Epilachna species which constitute an agricultural threat to food production thus said to have a considerable advantage over conventional pesticides [22]. Pharmacological Activities of this plant is very enormous it used as Insect repellent [21].

\section{Antibacterial Activity of Barringtonia Asiatica}

Khan and Omoloso [19] in their study on antibacterial, antifungal activities of Barringtonia asiatica reported crude methanol extract of Barringtonia asiatica (leaves, fruits, seeds, stem and root barks) and the fractions of (petrol, dichloromethane, ethyl acetate, butanol) exhibited a very good level of broad spectrum antibacterial activity. They reported that little work was done in this area with Barringtonia asiatica. The antibacterial and antifungal was reported by Antibacterial and Antifungal [19]. Dosage: To relieve the aching associated with malaria, inner bark is crushed and mixed with water and drunk, 2 cups per day for 2 days.

\section{Antifungal Activities}

The crude methanol extract of Barringtonia asiatica (leaves, fruits, seeds, stem and root barks) and the fractions (petrol, dichloromethane, ethyl acetate, butanol) exhibited a very good level of broad-spectrum antifungal activity. A number of fractions demonstrated antifungal activity against a number of fungi [19].

Khan et al., reported that all the fractions demonstrated a very good level of activity, which was significantly improved on fractionation. Antifungal activity was observed for a number of fractions against a few of the fungi. The methanol extract of Barringtonia asiatica flower had also exhibited the growth of Microsporum canis and Trichophyton rubrum at $1000 \mu \mathrm{g} / \mathrm{ml}$ while Epidermophyton floccosum at $125 \mu \mathrm{g} / \mathrm{ml}$ [20].

\section{Antidiabetic Activity}

The plant has been reported to be used for treatment of diabetes across the peninsula of India. It also has other traditional medicine purposes such as many ailments including treatments for haemolytic disease (various diseases of blood), abdominal colic, lumbar pain, syphilis, blennorrhoea, fever and malaria. Khan et al. [19] in their studies looked at the antibacterial activities of various ariel part of the plant Barringtonia asiatica and found out that all the fractions demonstrated a very good level of antibacterial activity, which was significantly improved on fractionation. Apart from the butanol fraction of the leaves, the dichloromethane fractions of the leaves and stem bark and ethyl acetate fractions of the seeds, fruits and root bark were particularly good with an inhibition rate between $18-20 \mathrm{~mm}$.

\section{Cytotoxicity and Safety}

Barringtonia asiatica seeds was reported have biological activity using the brine shrimp hatchability assay and lethality assay. The result as reported by Mojica and Micor, [14] that the dose dependent relationship on the activity and the concentration used. This was possible that the extract contained some substance with cytotoxicity activity. In their study the found out that during the phytochemical test using the crude extracts showed the presence of saponins and terpenoids [19,27,32]. Thus, in the seeds of Barringtonia asiatica and its related genus. it is possible that these compounds acting individually or synergistically were responsible for the observed activity of the extract. A keen interest researcher from Upolu, Western Samoa, collected seeds of this tree, Barringtonia asiatica and tested in the field for piscicidal activity using small fish from a river in Western Samoa. Some of the seed samples were placed in 70\% ethanol, following grinding in a water/ ethanol solvent mixture, removal of the pulp, and acidification, the liquid extract was exhaustively extracted with n-butanol. The solvent was removed, and the material was separated into its components using preparative reversed phase HPLC.

Using brine shrimp from the Great Salt Lake (Utah), the most retentive fraction was found to be most toxic. A literature search revealed that there had been very little work reported on compounds extracted from Barringtonia asiatica. Following careful purification of the active material, the structure of the most active piscicidal compound from the plant seed extract was determined and confirm of the presence of one glucose, one galactose, and a glucuronic acid unit as the most active component of the Barringtonia asiatica seed poison was determined to be a new compound: 3-0-\{[ $\beta$ D-galactopyranosyl-(1 $\rightarrow 3)$ - $\quad 2-\beta$-D-glucopyranosyl- $(1 \rightarrow 2)]-\beta-D$ glucuronopyranosyloxy\}- 21-0-\{[(2E )-2-methyl-1-oxo-2butenyl]

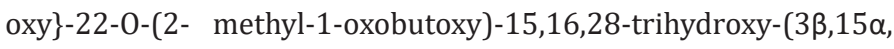
$16 \alpha, 22 \alpha$ )-olean-12-ene (Ranuncoside VIII). Figure 1a shows the structure. Recently, two other new saponins were isolated from the seeds of the plant seed, but neither was credited with piscicidal activity [19]. It was reported by Mojica and Micor [14], that Brine shrimp hatchability and lethality test assay were used to determine the biological activity of the Barringtonia asiatica (botong) seed's aqueous extract. For the hatchability test, inhibition of hatching was observed in at least $10 \mathrm{ppm}$ extract for $12 \mathrm{~h}$ and $100 \mathrm{ppm}$ for $24 \mathrm{~h}$ exposure. At lower concentrations (1-50 ppm), there is a dose dependent relationship wherein the percentage hatchability decreases as the concentration of the extract increases. They said that the low hatching rate observed after the $12 \mathrm{~h}$ treatment was probably due to an alteration in the development of Artemia embryos. Their studies have shown that Artemia is highly vulnerable to toxins at the early developmental stages [33,34]. They found out that the hatched brine shrimp nauplii treated with the crude extract were found to have deformities just like those observed in the positive control in comparison to the nauplii in the negative control.

In thier lethality/mortality test, the same dose dependent relationship just like the hatchability test was observed wherein the percentage mortality increases as the concentration of the 
extract increased. The LC50 was found to be 275.7, 32.34 and $2.25 \mathrm{ppm}$ for 12,24 and $48 \mathrm{~h}$ of exposure, respectively. This is higher in comparison to the positive control which have LC50 of 510.4, 139.4 and $20.25 \mathrm{ppm}$ for 12,24 and $48 \mathrm{~h}$ of exposure, respectively. Where the concluded that the activity increased significantly up to $48 \mathrm{~h}$ when exposure; particularly for the fruit extract. Maximum sensibility is usually reached after $48 \mathrm{~h}$ of exposure for the oldest age class nauplii tested [35]. Since at this stage, the life cycle of the nauplii have reached second and third instar and exhibit greatest sensitivity to test compounds [36]. Barringtonia asiatica seeds were tested for biological activity using the brine shrimp hatchability assay and lethality assay. Results showed dose dependent relationship on the activity and concentrations used. It is possible that the extracts contained substances with cytotocity activity Phytochemical tests using the crude extracts showed the presence of saponins and terpenoids.

Danar, [37] reported methanol seed extract of Barringtonia asiatica has insecticidal activity. However, its effect on Crocidolomia pavonana oviposition, fecundity, and food utilization efficiency were not observed yet. Barringtonia asiatica seed extract was tested with residual method application on mustard leaf at concentration of $0,02 \% ; 0,05 \% ; 0,1 \% ; 0,2 \% ; 0,3 \%$ and control to get LC50 value. The effect of Barringtonia asiatica seed extract on Crocidolomia pavonana (C. pavonana) fecundity according to [38], the residual method application of Barringtonia asiatica seed extract at concentration of $0.09 \%, 0.15 \%, 0.22 \%$ and control on mustard leaf was singnificant. The fecundity of adult insect develops from the larvae that feeding with treated food was observed. The effect of Barringtonia asiatica seed extract on oviposition of C. pavonana female was conducted by spraying seed extract at concentration of $0.66 \%, 0.77 \%$ and $0.96 \%$. The effect of extract on food utilization efficiency of C. pavonana larvae was done based on gravimetric method at concentration of $0.08 \%$; $0.14 \%$; and $0.21 \%$. The result of the research showed that Barringtonia asiatica seed extract were toxic on C. pavonana larvae with LC50 value of $0.15 \%$ and had antifeedant effect. Barringtonia asiatica seed extract at range concentration of $0.09 \%-0.22 \%$ delayed and inhibited egg production of C. pavonana. They reported that the Seed extract at concentration of $0,96 \%$ (equal with LC90 value) totally inhibited C. pavonana oviposition. Thus, the seed extract of Barringtonia asiatica caused decreasing of consumption rate (CR), relative consumption rate (RCR), growth rate (GR), and relative growth rate (RGR)of the larvae, so the ability of the larvae to damage crop become decreasing. Thus, in their research they conclude that the methanol seed extract of Barringtonia asiatica had strong insecticidal activity against C. pavonana larvae with LC50 value of $0.15 \%$ and had antifeedant effect [37].

Komansilan et al. [15], reported the effectiveness of vegetable insecticide extracts of hutun (Barringtonia asiatica Kurz) seeds on larvae of dengue haemorrhagic fever (DHF) vector Aides Aegyptus mosquito has been conducted. The test results indicate that there are differences in the real (significant) mortality level of mosquito larvae at various levels of concentration. In their test result of Probit Analysis shows the LC50 mortality concentration value of Ae- aegypti larvae with the provision of concentration of $35.572 \mathrm{ppm}$ is a concentration quantity value of the methanol extract of the hutun seeds which is the most effective way to kill the larvae of Ae-aegypti as much as $50 \%$ during 24 hours of treatment. According to their research the toxicity criteria, based on Australian Petroleum Energy Association, the concentration of 35.572ppm of seeds hutun methanol extract or (LC50 $=35.572 \mathrm{ppm}$ ) at 24 hours of observation is included in the criteria for Toxic Toxicity. Isaac et al. [26] in their studies of toxicity reported the toxicity of the plant. However, the result of the cytotoxicity showed that Barringtonia asiatica Leaf extract were toxic on brine shrimp larvae with LC50 value of 208.091 when compared with the control thymol at LC50 7.455. They referred to the fact that LC50 value of less than $1000 \mu \mathrm{g} / \mathrm{mL}$ is toxic while LC50 value of greater than $1000 \mu \mathrm{g} / \mathrm{mL}$ is non-toxic.

\section{Traditional uses of Barringtonia asiatica}

Traditional Medicinal Uses: The plant is used to treat fungal infections [20]. The plant was reported to heal burns and wounds by Woodley, in [39]. The leaves are heated and used to treat stomach ache and rheumatism in the Philippines while the fruits are used as a fish poison and the fruit juice for controlling scabies. The seeds are used for the expulsion of intestinal worms and also as a fish poison [40]. The plant Barringtonia asiatica are also used to treat sores, cough, influenza, sore throat, diarrhoea, swollen spleen after malaria [41]. The plant is also used in Vietnam, the fresh nut is scraped and applied to sores; dried nut is ground into a powder, mixed with water and drunk to cure coughs, influenza, sore throat, bronchitis, diarrhoea and swollen spleen [39]. However, the bark is used in the treatment of tuberculosis [41]. In Yambio (Sudan), the inner bark is crushed and mixed with water and drunk to ease the aching associated with malaria. Barringtonia asiatica bark when combined combination with other plants it acts effectively as a medicine to treat tuberculosis in New Ireland and the Solomon Islands [39]. Insect repellent of Barringtonia asiatica was reported by Herlt [21]. Antibacterial and Antifungal [19], the dosage to relieve the aching associated with malaria, inner bark is crushed and mixed with water and drunk, 2 cups per day for 2 days. The fruits and seeds as reported by Khan et al. [19] were used as fish poison, fruit juice for controlling scabies, leaves applied to stomach ache and rheumatism, seeds as vermifuge, nuts used to treat sores, cough, influenza, sore throat, diarrhea, swollen spleen after malaria and bark for tuberculosis.

\section{Conclusion}

The plant of Barringtonia asiatica ariel parts and as a whole possess a wide array of pharmacological and phytochemical properties, which reflect their health benefits, and confer their 
traditional uses as food and medicine. They include antioxidant, antibacterial, antiviral, antifungal, insecticidal, cytotoxic hypoglycaemic, hypolipidemic, hypocholesterolemic, antiulcerogenic, anti-hypertensive, analgesic and anti-inflammatory activities. On the contrary, only pharmacological, antimicrobial, cytotoxic, and few of the phytochemical have been reported in some of the ariel parts of the plant Barringtonia asiatica, unlike other Barringtonia species which have many more bioactivities. The Leave, stem-bark, and seed of Barringtonia asiatica are used as fish poison. One would therefore assume that the excessive consumption of these herbs may be detrimental to the human health, contrary to the belief that the regular intake of the herbs has health promoting properties and can assist in preventing degenerative diseases, delaying aging and improving overall health. With the update of this review I believe further studies can be conducted on the phytochemical and pharmacological properties of these plant Barringtonia asiatica.

They include isolating and identifying novel bioactive compounds; assessing the properties and elucidating the mechanisms of action of the isolated compounds; analyzing the effects of different processing methods on these plants; evaluating their toxic effects; and exploring their potentials of developing as herbal and pharmaceutical products. Notwithstanding, the prospects of studies on new phytochemical and pharmacological properties are equally promising if scientific studies is intensified and have indeed verified its worth exploring properties, Barringtonia asiatica may serve as a potential candidate for a future drug development.

\section{References}

1. Thiel Martin, Gutow L (2005) The ecology of rafting in the marine environment. I. The floating substrata. Oceanography and Marine Biology: an annual review 42: 181-264.

2. Cannon JG, Burton RA, Wood SG, Owen NL (2004) Naturally occurring fish poisons from plants. Journal of chemical education 81(10): 14571461.

3. Tsou CH, Mori SA (2002) Seed coat anatomy and its relationship to seed dispersal in subfamily Lecythidoideae of the Lecythidaceae (the Brazil nut family). Botanical Bulletin of Academia Sinica 43: 37-56.

4. Thaman RR (1992) Receptors Batiri Kei Baravi, the ethnobotany of the pacific island coastal plants. Atoll Research Bulletin 361: 1-62.

5. Chopra RN (1958) ( $2^{\text {nd }}$ edn revised and largely rewritten), Chopra's Indigenous Drugs of India. Calcutta, UN Dhur \& Sons Private Ltd, India, p. 584.

6. Howes FN (1930) Fish-poison Plants. Kew Bulletin Miscellaneous Information 1930(4): 129-153.

7. Barrau J (1955) Fishing poisons of the south pacific. SPC Q Bull p. 7-8.

8. Crosby MR, Magill RE, Allen B, He S (2000) A checklist of the mosses. St Louis, Missouri Botanical Garden, USA, pp. 55-246.

9. Prance G (2012) A Revision of Barringtonia (Lecythidaceae). Allertonia pp. 1-161.

10. Ria Tan (2001) Sea poison Tree. Mangrove and wetland wildlife at Sungei Buloh Nature Park. Singapore.
11. Meyer BN, Ferrigni NR, Putnam JE, Jacobsen LB, Nichols DJ, et al. (1982) Brine shrimp: a convenient general bioassay for active plant constituents. Planta medica 45(5): 31-34.

12. Molina-Salinas GM, Said-Fernández S (2006) A modified microplate cytotoxicity assay with brine shrimp larvae (Artemia salina). Pharmacologyonline 3: 633-638.

13. Mojica ERE, Micor JRL (2007) Bioactivity study of Barringtonia asiatica (Linnaeus) kurz. seed aqueous extract in Artemia salina. International Journal of Botany 3(3): 325-328.

14. Komansilan A, Suriani NW (2016) Effectiveness of Seed Extract Hutun (Barringtonia asiatica KURZ), on LARVA Aedes aegypti Vector Disease Dengue Fever. International Journal of Chem Tech Research 9(4): 617624.

15. Sumalatha G, Manjeera K, Umamahesh B, Sandhya RG (2011) Screening of wound healing effect of bark of Barringtonia asiatica. International Journal of Pharmacology Research 1(1): 26-31.

16. Kumar B, Vijayakumar M, Govindarajan R, Pushpangadan P (2007) Ethnopharmacological approaches to wound healing-exploring medicinal plants of India. Journal of Ethnopharmacology 114(2): 103113.

17. Tanor MN, Abadi AL, Rahardjo BT, Pelealu J (2014) Isolation and Identification of Triterpenoid Saponin from Baringtonia asiatica Kurz Seeds. Journal of Tropical Life Science 4(2): 119-122.

18. Khan M R, Omoloso AD (2002) Antibacterial, antifungal activities of Barringtonia asiatica Fitoterapia 73(3): 255-260.

19. Locher CP, Burch MT, Mower HF, Berestecky J, Davis H, et al. (1995) Antimicrobial activity and anti-complement activity of extracts obtained from selected Hawaiian medicinal plants. Journal of ethnopharmacology 49(1): 23-32.

20. Herlt AJ, Mander LN, Pongoh E, Rumampuk RJ, Tarigan P (2002) Two major saponins from seeds of Barringtonia asiatica: putative antifeedants toward Epilachna sp larvae Journal of natural products 65(2): 115-120.

21. Pongoh E (1997) Isolation and Identification of Antifeedant Saponin Compound from Seeds of Barringtonia asiatica L Kurz with Bioindicator Epilachna sparsa M.Sc. Thesis Padjadjaran University, Bandung, Indonesia.

22. Iwashina T, Kokubugata G (2016) Flavonoid Properties in the Leaves of Barringtonia asiatica (Lecythidaceae). Bull Natl Mus Nat Sci Ser B 42(1): 41-47.

23. Rahman MM, D Polfreman, J MacGeachan, A Gray (2005) Antimicrobial activities of Barringtonia acutangula. Phytother Res 19(6): 543-545

24. Ragasa C Y, Espineli DL, Shen CC (2011) New triterpenes from Barringtonia asiatica. Chemical and Pharmaceutical Bulletin 59(6): 77878

25. Isaac John Umaru, Fasihuddin A Badruddin, Zaini B Assim, Hauwa A Umaru, Dluya Thagriki (2018) Antibacterial and Cytotoxicity Studies of Barringtonia Asiatica. Anatomy Physiology and Bio chemistry 5(3).

26. Burton RA, Wood SG, Owen NL (2003) Elucidation of a new oleanane glycoside from Barringtonia asiatica. Arkivoc 13: 137-146.

27. Gupta S, Portwal MC, Roy PS (2004) Indigenous knowledge on some medicinal plants among the Nicobari Tribes of Car Nicobar Island. Indian J Traditional Knowl 3(3): 287-293.

28. Dam Roy S (1996) Effect of Barringtonia asiatica (Linn.) Kurz as a fish poison on weed fishes and predatory fishes. J Andaman Sci Assoc 12(12): $97-100$.

29. Whistler A (2000) Plants in Samoan Culture. Honolulu: Isle Botanic.

30. Gorre T, Bhikku A, Nagulu M, Rani G (1984) Anti-epileptic activity of Barringtonia Asiatica (L.). International Journal of Pharmacological Screening Methods 1(1): 20-24. 
31. Yang Y, Z Deng, P Proksch, W Linn (2006) Two new 18-en-oleane derivatives from marine mangrove plant, Barringtonia racemosa. Pharmazie 61: 365-366.

32. Sorgeloos P, Remiche Van Der Wielen C, Persoone G (1978) The use of Artemia nauplii for toxicity tests-a critical analysis. Ecotoxicology and environmental safety 2(3-4): 249-255.

33. Sleet R B, Brendel K (1985) Homogeneous populations of Artemia nauplii and their potential use for in vitro testing in developmental toxicology. Teratogenesis carcinogenesis and mutagenesis 5(1): 41-54.

34. Sánchez-Fortún S, Sanz F, Barahona MV (1996) Acute toxicity of several organophosphorous insecticides and protection by cholinergic antagonists and 2-PAM on Artemia salina larvae. Archives of environmental contamination and toxicology 31(3): 391-398.

35. Lewis GE (1995) Testing the toxicity of extracts of Southern African plants using brine shrimp (Artemia salina). South African Journal of
Science 91(8): 382-384.

36. Danar Dono (2008) Bioactivity methanolic seed extract of Barringtonia asiatica (Lecythidaceae). Proceeding of The International Seminar on Chemistry Jatinongor pp. 589-594.

37. Dono D (2008) Bioactivity methanolic seed extract of barringtonia asiatica (lecythidaceae) against Crocidolomia pavonana (lepidoptera: pyralidae): In International Symposium of Biochemistry. Departement Biochemistry, Padjadjaran University, Bandung, Indonesia, p. 30-31.

38. Woodley E (Ed.) (1991) Medicinal plants of Papua New Guinea, part I. Veerlag Josef Margraf Scientific Books: Weikersheim.

39. Perry L M, Metzger J (1980) Medicinal plants of east and southeast Asia: attributed properties and uses. MIT press USA pp.620.

40. Steiner R P (1986) Folk medicine: the art and the science. American Chemical Society: Washington DC, USA 7(2): 223.

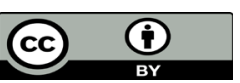

This work is licensed under Creative Commons Attribution 4.0 License

Submission Link:

Submit Article

DOI: $10.32474 /$ DDIPIJ.2018.02.000138

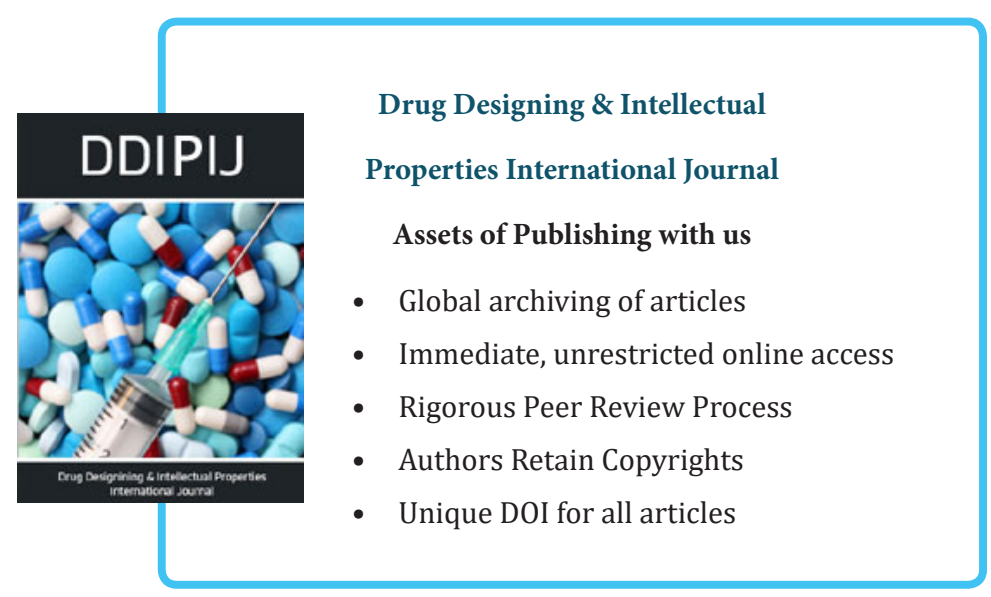

